\title{
An Effective Immobilizing Agent for Hybrids of European Bison and Domestic Cattle
}

\author{
Bogdan F. KANIA, Edward SUMIŃSKI \& Jacek KOSSAKOWSKI
}

Kania B. F., Sumiński E. \& Kossakowski J., 1985: An effective immobilizing agent for hybrids of European bison and domestic cattle. Acta theriol., 30, 27: 435-444 [With 1 Table]

It was found that a neuroleptic-analgesic complex named Immobyl (fentanyl and azaperone) is as effective and safe for the immobilisation of F1 and B1 hybrids as is etorphine (Cripavin). The length of time between the application of this agent and the first effects, the intensity of the immobilisation effect and its duration are highly favourable when compared with other agents (Xylazine, Suxamethonium). The existence of reliable antagonists like cyprenorphine, diprenorphine and nalorphine increases the practical value of Immobyl.

[Dept. Pharmacol. Toxicol., Warsaw Agric. Univ. Nowoursynowska 166, 02-766 Warsaw (FK, ES) and Inst. of Genetics and Animal Breeding PAS, 05-551 Mroków, Jastrzębiec (JK), Poland]

\section{INTRODUCTION}

After a series of investigations on wild ruminants with etorphine (Kania et al., 1973, 1974, 1975), European bison $\times$ cattle hybrids were taken to examine the effect of a neuroleptic-analgesic agent, containing 50 parts of fentanyl ( $R$ 4263) and 10 parts of azeperone ( $R$ 1929), known as Immobyl, and produced by Janssen Pharmaceutica, Beerse, Belgium.

Fentanyl is an analgesic drug with a narcotic effect from the group of the 4-anilino-piperidine series, obtained semisynthetically. Its analgesic effect is about 100 times stronger than that of morphine and about 700 times more potent than pethidine (Janssen Pharmaceutica;, 1969). The reaction comes soon after administering by way of intramuscular injection. Its maximum effect lasts $30 \mathrm{~min}$. while the general reaction several hours. One may expect that as an agent similar to morphine it may inhibit the polisynaptic reflexes of the spinal cord, similarly as morphine (Grossmann et al., 1973; Jurna, 1966). Morphine and similar agent cannot be effectively used for ruminants, as they cause a motorical excitation, difficult to control. Therefore the commercial agent contains another compound, azaperone, which is a butyrophenone derivative (Marsboom, 1969). A combination of two agents, thus creating a neuroleptic-analgesic complex, is often used in both medical and veterinary anaesthesiology. The condition obtained after 
the use of such components is called neuroleptanalgesia (NLA). The advantage of NLA lies in its additive or superadditive effect of joined agents, which makes it possible to decrease the dose of each drug, increasing the safety of their application and causes a complete elimination of pain with a limited consciousness, limits to a minimum the possibility of unfavourable effects and shortens the post-narcotic period. The existence of a specific antagonist allows a quick recovery of the animal (Pienaar, 1968b), at any moment.

The previous, successful experiments on laboratory, domestic and wild animals (Kania, 1973; Kania \& Teuchmann, 1974; Kania, 1975; Kania \& Teuchmann, 1975; Pienaar, 1975) encouraged to use an agent, theoretically not as strong as etorphine, but applied together with a neuroleptic. Another, important reason, was the greater accessibility of Immobyl.

Thus it was decided to examine the value of this preparation for the immobilisation of F1 and B1 European bison hybrids. Eriksen (1968), Keep (1973), King \& Klingel (1965), Mortelmans (1971), Mortelmans \& Vercruysse (1971), Pienaar (1975) used on wild herbivorous mammals doses of fentanyl not high, together with similar or much higher doses of fluanizone and acetylpromazine or acetylpromazine, azaperone or even scopolamine with good results. In the present study an original agent (Immobyl) was used. Afterwards administration of antagonists and symptoms accompanying remobilization were investigated.

\section{MATERIAL AND METHODS}

The experiments were conducted on 23 animals at the Jeziory Wielkie Breeding Centre (outside Poznań). For experiments were designated 16 F1 hybrids (European bison $\times$ cattle), 2 females and 14 males, 12-18 months old, at a mean body weight of about $285 \mathrm{~kg}( \pm 10 \%)$, and $7 \mathrm{~B} 1$ hybrids $(3 / 4$ European bison and $1 / 4$ cattle), males, aged about 8-11 months, at a mean body weight of about $277 \mathrm{~kg}$ $( \pm 10 \%)$.

The F1 hybrids were divided into 4 groups 4 animals in each. Animals from group I received Immobyl and during the time of its strongest immobilizing effect, i.e., after $20 \mathrm{~min}$; cyprenorphine (M 285) in a dose 5 times lower than that of the agonist (Immobyl). The II group received only the agonist, so as to determine the length of time between administration and reaction, the length of the immobilizing effect, the accompanying symptoms and the behaviour of animals when the influence of the agonist expired. Group III received Immobyl, and during the time of its strongest immobilizing effect - diprenorphine (Revivon), in a dose about twenty times lower than that of the agonist. Group IV received Immobyl and during the time of its strongest effect - nalorphine (Nalline), in a dose about two and a half stronger than that of the agonist (Table 1).

The B1 hybrids were divided into two groups ( 3 and 4 animals). Both groups received Immobyl and during the time of its strongest immobilizing effect group I 
received cyprenorphine in a dose about 5 times lower and group II - diprenorphine, in a dose about twenty five times lower than that of the agonist (Table 1).

As an agonistic (immobilizing) agent Immobyl was used, which contains in $1 \mathrm{~cm}^{3}$ solution $50 \mathrm{mg}$ of fentanyl and $10 \mathrm{mg}$ of azaperone.

The animals were shot with syrrings missiles, aiming at the musculus gluteus from a distance of $10-40$ metres.

As antagonistic agent were used: Cyprenorphine hydrochloride (M 285, Reckitt \& Colman), Diprenorphine hydrochloride (Revivon, Reckitt \& Colman) and Nalorphine hydrochloride in substantia (Janssen Pharmaceutica, Beerse), from which, suitable concentrations were prepared ex tempore, and injected directly intramuscularly.

\section{RESULTS}

In group I (Table 1), 3 min after the shot no changes in the behaviour of the animals were observed. Next there appeared a "vocalisation", and after $5 \mathrm{~min}$ two animals begune to salivate. If animals were frightened prior to the injection, after $6 \mathrm{~min}$ there occured a motoric stimulation, manifested by running, head shaking, disturbing other animals in the group and bellowing. This lasted about 3 min. After 9 min instability, lowering of the back, wide placeing of hinde legs and stumbling on uneven ground or on other animals were observed. On an average in the 17 th $\mathrm{min}$. after the injection the animals lied down, on their sternum, and access to them became quite safe. The immobilization obtained made it possible to undertake reanimation steps directly on the animal, to deepen the narcosis for conducting operations, and also for preparing the animal for transport.

The antagonists solution prepared, i.e., cyprenorphine, was injected intramuscularly (i.m.), the mean dose being $51.05 \mathrm{mcg} / \mathrm{kg}$ b.w. About $11 \mathrm{~min}$ after the cyprenorphine injection the animals rose and, first unsteadily, then already normally, moved away into the pen. Side effects were not observed. The next day all the animals came to feed and their behaviour did not differ from that of other animals in the group.

In group II (Table 1), $3 \mathrm{~min}$ after the injection, three out of four animals tested "vocalised", and the fourth one, frightened prior to the injection, was restless, running and bellowing for about 2 min. About $5 \mathrm{~min}$ after releasing the missile, unsteadiness and lowering of the back was observed. The animals took the position of a sitting dog, next lied down on the sternum, and finally on their side. Three animals were observed to salivate, the ton gue of the fourth came out between the 30 th and 90 th $\mathrm{min}$ after the injection, and his legs were moving. All the animals increase the breathing rate during the whole time of the drug's activity. From 23 breaths/min to 29 breaths/min after $30 \mathrm{~min}$ the injection and to $32 \mathrm{breaths} / \mathrm{min} 180 \mathrm{~min}$ later. $90 \mathrm{~min}$ 
after injection the animals attempted to rise but without success. The mean time of the deep action of the drug was about $90 \mathrm{~min}$, while some effects could be observed till about $218 \mathrm{~min}$. After rising the animals moved away to the rest of the group, bellowed from time to time and

Table 1

Agents used, dosage and action on the F1 and B1 European bison $\times$ cattle hybrids.

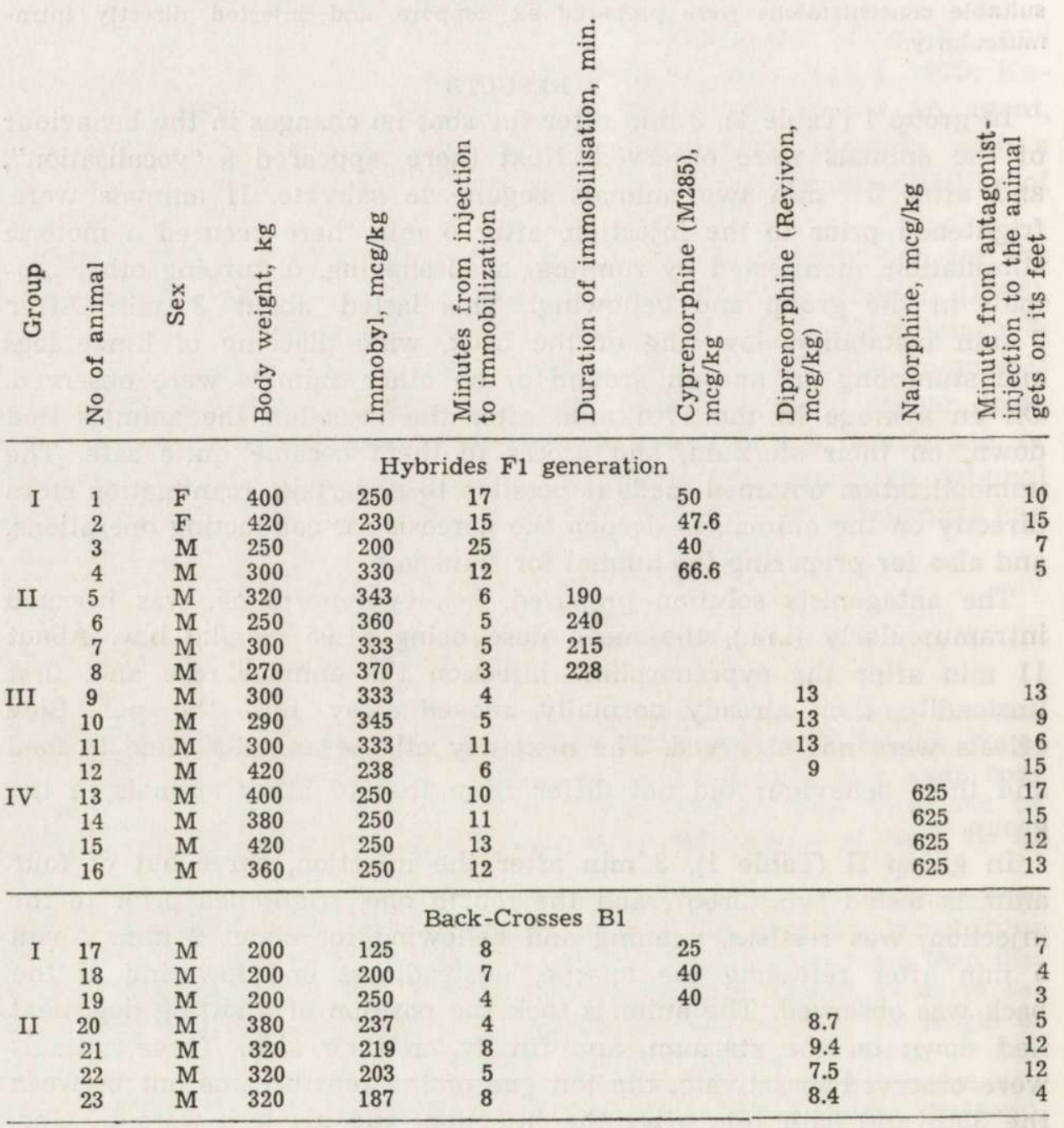

generally disturbed the other animals. This type of behaviour lasted for an average of about $50 \mathrm{~min}$.

In group III (Table 1), four min after the shot all the animals demonstrated "vocalisation", and in 3 animals an immobilisation similar to 
that described for the previous group, occured after $5 \mathrm{~min}$. One animal, frightened prior to the injection demonstrated an increased activity characterised by running, pressing on the other animals, head shaking and butting between 7 th and 11 th $\mathrm{min}$. The immobilisation occurred in this animal after $12 \mathrm{~min}$. $15 \mathrm{~min}$ after the shot a biopsy of the testes was performed on all the animals, under local anaesthetic for other purposes. $38 \mathrm{~min}$ after administration the agonist an adequately prepared solution of the antagonist, i.e., diprenorphine, was injected i.m. - mean dose $12.15 \mathrm{mcg} / \mathrm{kg}$ b.w. After about $11 \mathrm{~min}$ the animals rose and moved towards the rest of the group. No side effects were observed. On the next day the behaviour of these animals was normal.

In group IV (Table 1), the animals lied down about $11.5 \mathrm{~min}$ after shooting. About $30 \mathrm{~min}$ after administration the agonist, an i.m. injection was made of an antagonist solution, i.e., nalorphine - average dose $625 \mathrm{mcg} / \mathrm{kg}$ b.w., in $0.125 \mathrm{~cm}^{3}$ of water, so that the a average volume injected into one animal amounted to about $50 \mathrm{~cm}^{3}$. About $14 \mathrm{~min}$ after the injection of the antagonist the animals rose and moved away from the place where they were immobilized. About 7 min later they began bellowing, running and moving away from the herd. Those symptoms remained, with various intensity, for about 60 minutes.

In the first group of B1 hybrids (animals 17-19, Table 1), the reaction of each animal was slightly different. Animal No. 17, $2 \mathrm{~min}$ after the shot demonstrated "vocalisation", between the 4th and 6th min was running arround the pen, in the 6 th $\min$ approached the research workers and in the 8th quietly lied down on its sternum. A strong constriction of the sphincter anus was then observed. The animal No. 18, in the 1st min after the injection kicked backward, in the 3rd min the "vocalisation" occurred and in the 4th min placeing hind legs wide and lied down on the sternum. The eversion of the anus was then observed. The animal No. 19, demonstrated an unstable back in the 2nd min after the shot, and pressed against obstackles by a head. In the 3rd min "vocalisation" occured and in the fourth lied down on its sternum. A paralysis of the right eye ball was then observed. Both pupills become dilated and after the animal lied down on its side apnoea occurred, which would indicate an oversensitivity to this drug. In the 11 th min of the immobilisation a deep i.m. injection of cyprenorphine, mean dose $35 \mathrm{mcg} / \mathrm{kg}$ b.w. was made. About $5 \mathrm{~min}$ after the animal rose.

B1 hybrids (animals 20-23, Table 1), reacted differently, despite a similar weight, age and dose of the agonist. Animal No 20 in the 1st min after the shot urinated, "vocalisation" occurred during the 2nd min, during the $3 \mathrm{rd}$ min an unstability of the back and wide placeing 
of the hind legs and in the 4th min the animal lied down. In the 13th min the penis fall out. The animal No 21 was, between the $3 \mathrm{rd}$ and 6 th $\mathrm{min}$, uneasy, run arround the pen and bellowed. In the 8th min its hind legs gave way and the animal lied down. At the same time one could observe a gnashing of teeth. In turn, the animal No 22 urinated during the 1st min after the shot, showed an unsteable back in the 2nd, in the 4th climbed on obstackles and salivated. In the 5th min it lied down, and in the 10th there occurred and eversion of the anus, an increase of the breathing rate and falling out of the tongue. The animal No 23 "vocalized" in the 2nd $\mathrm{min}$, in the 3rd there occurred a wide placeing of the hind legs end in the fourth - salivation and trottering around the pen for $3 \mathrm{~min}$. In the 8 th min the animal lied down on the sternum and an eversion of the anus occured.

After about $20 \mathrm{~min}$ of immobilisation all these animals received an i.m. injection of diprenorphine, mean dose amounting to $8.5 \mathrm{mcg} / \mathrm{kg}$ b.w. After about $6.5 \mathrm{~min}$ the animals stood up. Three out of the four animals, after returning to a normal position, moved over to the remaining animals and their behaviour did not differ from normal. The animal No. 20, 6 min after standing up, started trotting arround the pen, and continued it for about $26 \mathrm{~min}$, after which it joined the herd. The next day all the tested animals behaved similarly to those not subjected to experiments.

\section{DISCUSSION}

Immobyl was as effective and as safe for European bison hybrids immobilisation as etorphine (Kania et al., 1973; Kania \& Teuchmann, 1974; Kania, 1975; Pienaar, 1968; Pienaar, 1975). The time between the injection and the reaction ( $\pm 8 \mathrm{~min})$, the strength of the immobilizing effect and the length of its complete effect $( \pm 90 \mathrm{~min})$ are highly favourable when compared with other agents used with this aim (Chloral hydrate - Jaczewski \& Swieżyński, 1955; Piwowarczyk, 1967, Xylazine - Kroneberg et al., 1967, or Suxamethonium - Zaniewski, 1967).

It is possible that, in the wild animals a considerable part in conveying impulses in the spinal synapses is played, beside acetylcholine $(\mathrm{AcCH})$ and 5 -hydroxytryptamine $(5-\mathrm{HT})$, also by noradrenaline (NA) and dopamine (DA). Our recent works conducted on the inhibiting inotrope effect of Immobyl on the hind limb flexor activity of spinal rats indicate undoubtedly the share of the alfa-adrenergic receptor in this mechanism (Kania, unpubl. data).

Morphine and its derivatives or substitutes compete with the receptor impulse mediators both in the highest centres of the central nervous system (CNS), (Kuschinsky \& Hornykiewicz, 1972; Teuchmann \& 
Kania, 1977), and in the spinal cord (Grossmann et al., 1973); Jurna, 1966), and dislodging them from the receptors they strengthen the depression effect. Earlier studies (Kania, 1977; Teuchmann \& Kania, 1977) indicate that fentanyl (the principal component of Immobyl) causes an inhibition of the liberation of both DA and NA from the presynaptic elements of the spinal cord (Kania, 1977; Kania, 1980). The final effect of such activity is a significant increase of the DA and NA concentration in the spinal cord by $282 \%$ and $133 \%$ respectively. These results also indicate the participation of the spinal cord dopaminergic receptor in the mechanism of fentanyl activity. It is also possible that the activity 'of Immobyl is similar to that of neuroleptics. The later, blocking the lopaminergic receptor intensify the rate of synthesis and catabolisation of released neurotransmitters. Our suggestion is supported by the fact that after using neuroleptics the global quantity of biogenic amines significantly decreases contrary to their increase as is the case of fentanyl administration (Kania, 1980).

Under the influence of Immobyl animals stop being timid and agressive, and it is possible for a human being to approach them safely. Depending on the gradation of doses one may obtain a condition of complete NLA. The effect of Immobyl is sufficiently long to make operations safely, and also for transportation of animals.

The existence of fentanyl antagonists, such as cyprenorphine used in a dose 5 times lower than that of fentanyl, diprenorphine - used in a dose 25 times lower, or nalorphine used in a dose 2,5 times higher than that of fentanyl - which reverse the condition of total immobilization during about $8 \mathrm{~min}$ increases the practical value of the method.

Our results indicate, that a dose ensuring complete immobilisation amounted to $300 \mathrm{mcg}$ of fentanyl and $60 \mathrm{mcg}$ of azaperone per $1 \mathrm{~kg}$ b.w. for F1 hybrids and it was about 33\% lower for B1 hybrids, ammounting 200 and $40 \mathrm{mcg}$ respectively. This indicates a greater sensitivity of B1 hybrids to the drug used, all the more so, as each of the animals reacted slightly differently, despite similar doses used for those animals. Average time till the complete immobilization in B1 hybrids occurred was $6.3 \mathrm{~min}$ and it was shorter by $3 \mathrm{~min}$ from that necessary to obtain an immobilization of F1 hybrids. Similarly, the mean length of time necessary to reverse the condition of total immobilization (after using antagonists) was shorter in the case of B1 hybrids and amounted to an average of $5 \mathrm{~min}$, while in the case of $\mathrm{F} 1$ hybrids it reached $10 \mathrm{~min}$. This may indicate a greater sensitivity of B1 hybrids also to the agents used as antagonists to Immobyl.

The mean duration of the total immobilization after Immobyl in 
European bison and domestic cattle hybrids corresponds with the data of other authors obtained on other species of wild artiodactyls (Eriksen, 1968; Pienaar, 1975). These authors administered doses of fentanyl two or three times lower than those used in our work, and together with two or three times higher doses of neuroleptics of the fluanizone or acetylpromazine type, or even with scopolamine. One must emphasise that increase of the doses of neuroleptics at the cost of fentanyl and an additional dose of a vagolytic makes it possible to limit the negative side effects of fentanyl observed by us, such as a short motoric excitation, "vocalisation", salivation, urination or defecation. These symptoms indicate a stimulation of the parasympathetic system. However, it seems that tachycardia, for instance in sheep, occurring after the administration of Immobyl, indicates its winder range of activity i.e., that is has an acetylcholinomimetic effect, including also a sympathicotonic effect, arising from a stimulation of the ganglion nicotinic receptor.

It is characteristic, that in the case of 6 animals, frightened prior Immobyl administration, the condition of complete immobilization was preceded by a period of motoric exciatation lasting $3-5 \mathrm{~min}$, while animals not frightened did not demonstrate this unfavourable effect.

\section{REFERENCES}

1. Eriksen E., 1968: Medikamentel immobilisering og faengsling af dyr. III. Sedation og anaestesi af zoo dyr. Saertryk af Nord. Veterinaermed., 20: 657-679.

2. Grabowska M., 1973: Związki stymulujące ośrodkowe receptory katecholaminowe. Post. Hig. Med. dośw., 27: 209-243.

3. Grossmann W., Jurna I., Nell T. \& Theres C., 1973: The dependence of the anti-nociceptive effect of morphine and other analgesic agents on spinal motor activity after central monoamine depletion. Eur. J. Pharmacol., 24: $67-77$.

4. Jaczewski Z. \& Swieżyński K., 1955: Anaesthesis in the European bison (Bison bonasus L.) by chloralhydrate (chloralum hydratum). Zool Pol., 6: 80-87.

5. Janssen Pharmaceutica, 1969: Immobilization and restraint of large wild animals with azeperone and fentanyl (instruction). Beerse: 1-16.

6. Jones L. M., Booth N. H. \& McDonald L. E., 1978: Veterinary pharmacology and therapeutics. The Iowa State Univ. Press: 318-326 and 373-394, AMES.

7. Jurna I., 1966: Inhibition of the effect of repetitive stimulation on spinal motoneurones of the cat by morphine and petidine. J. Neuropharmacol., 5: $117-122$.

8. Kania B. F., Teuchmann J. K., Piwowarczyk S., \& Krasiński Z., 1973: Pharmacological aspects of immobilizing effects of M 99 on Bison bonasus L. and attemps to antagonize these effects with M 285. Przegl. zool., 2: 242-247.

9. Kania B. F. \& Teuchmann J. K., 1974: Etorphine hydrochloride (M 99) a new 
potent drug for immobilization of European bison (Bison bonasus L.). Nowości wet., 2: $227-234$.

10. Kania B. F., 1975: Neuroleptanalgesic and immobilizing action of etorphine on domestic ruminants. Med. wet., 3: 158-161.

11. Kania B. F. \& Teuchmann J. K., 1975: The use of etorphine hydrochloride (M 99) as an immobilizing agent in the European bison (Bison bonasus L.). Zool. pol., 2/3: 85-89.

12. Kania B. F., 1977: The effect of etorphine on dopamine and noradrenaline concentrations in different central nervous system structures in the rat. Acta physiol. pol., 28: 529-540.

13. Kania B. F., 1979: Studies on the mechanism of postetorphine catalepsy. Modyfying effect of amphetamin, apomorphine and dihydroxyphenylalanine (1-DOPA) on etorphine induced concentrations of dopamine and noradrenaline in the rat central nervous system. Acta physiol. pol., 2: 279-287.

14. Kania B. F., 1980: Studies on the mechanism of postetorphine catalepsy. Effects of clotiapine, haloperidol and Rompun on postetorphine changes in concentrations of dopamine and noradrenaline in central nervous system of rats. Acta physiol. pol., 1: 9-16.

15. Keep J. M., 1973: Notes on the field capture of the agile wallaby (Macropus agilis). Austral. Vet. J., 49: 385-387.

16. King J. M. \& Klingel H., 1965: The use of the oripavine derivative M 99 for the restraint of equine animals and its antagonism with the related compound M 285. Rev. Vet. Sci., 6: 447-455.

17. Kroneberg G., Oberdorf A., Hoffmeister F. \& Wirth W., 1967: Zur pharmakologie von 2-/2,6-Dimethylphenylamine/4H-5,6-Dihydro- 1,3 thiazin (Bayer 1470) eimes Hemstoffes adrenergischer und cholinergischer Neurone. Archiv. Pharm. exp. Path., 256: 257-260.

18. Kuschinsky K. \& Hornykiewicz O., 1972: Morphine catalepsy in the rat: relation to striatal dopamine metabolism. Eur. J. Pharmacol., 19: 119-122.

19. Marsboom R., 1969: On the pharmacology of azaperone, a neuroleptic used for the restraint of wilde animals. Acta zool. path. antv., 48: 155-158.

20. Mortelmans J., 1969: Tranquilisation and Anaesthesia. Primates in Medicine, 2: $113-122$.

21. Mortelmans J. \& Vercruysse J., 1971: Immobilization and analgesia in wild animals in captivity. Verhandlungsber. XIII. Internat. Symp. Erkrankungen Zootiere, Helsinki, 203-206.

22a. Pienaar U. de V., 1968: The use of immobilizing drugs in conservation procedures for Roan Antylope. Acta zool. path. antv., 46: 39-51.

22b. Pienaar U. de V., 1968: Recent advances in the field immobilization and restraint of wild ungulates in South African National Parks. Acta Zool. Path. Antv., 46: $17-38$.

23. Pienaar U. de V., 1969: The use of drugs in the field immobilization and restraint of wild mammals in South African National Parks. Acta Zool. Path. Antv., 48: 163-177.

24. Pienaar U. de V., 1975: The drug immobilisation of South Africa antelope species (unpublished data - pp 17).

25. Piwowarczyk S., 1967: Narcosis induced in European bison by means of chloral hydrate and ethyl alcohol. Acta theriol., 32: 467-470.

26. Sagner G., Hoffmeister F. \& Kroneberg G., 1968: Pharmakologische Grundla- 
gen eines neuartigen präparates für die Analgesie, Sedation and Relaxation in der Veterinärmedizin (Bay Va 1470). Dtsch. tierärztl. Wschr., 75: 565-582.

27. Stille G. \& Lauener H., 1971: Korrelation zwischen neuroleptischer katalepsie und homowanillinsäueregehalt im Corpus striatum bei Ratten. Arzneim. Forsch., 21: $800-808$.

28. Teuchmann J. K. \& Kania B. F., 1977: The effect of etorphine, fentanyl and morphine on dopamine and noradrenaline concentrations in the striatum of rat. Acta physiol. pol., 2: 107-112.

29. Vertessen K., 1970: Immobilizatie van everzwijnen middel van azaperone en fentanyl. Tijdschr. Diergeneesk., 10: 541-543.

30. Zaniewski L., 1967: The immobilization of European bison $\times$ cattle hybrid with suxamethonium. Acta theriol., 12: $471-474$.

Accepted, May 6, 1985.

Bogdan F. KANIA, Edward SUMIŃSKI i Jacek KOSSAKOWSKI

EFEKTYWNY SRODEK OBEZWŁADNIAJACY DLA ŻUBRONI I ZUBROIDOW

\section{Streszczenie}

Określano działanie przygotowanej specjalnie mieszanki analgetyczno-neuroleptycznej pod nazwą Immobyl (Janssen Pharmaceutica, Beerse, Belgium) na żubronie i żubroidy (mieszańce $3 / 4$ krwi żubra) w ośrodku hodowlanym Jeziory Wielkie k/Poznania. Stwierdzono, że preparat ten jest również efektywny i bezpieczny jako etorfina (M 99, Oripavin) dla obezwładniania żubroni i żubroidów. Czas wystapienia pełnego działania dla preparatu określono na około $8 \mathrm{~min}$, pełne dzialanie obezwładniające tego preparatu wynosiło około $90 \mathrm{~min}$. Wyniki te sa bardzo korzystne w porównaniu do innych środków (Chloralum hydratum, Rompun, Suxamethonium), stosowanych dla obezwładniania zwierząt.

Posiadanie niezawodnych antagonistów typu cyprenorfiny, diprenorfiny bądź nalorfiny podnosi praktyczną użyteczność Immobylu.

Immobyl może być rekomendowany dla trudnych do obezwladniania zwierząt jakimi są dzikie przeżuwacze a zwłaszcza dla żubroni i żubroidów. 